\title{
PENGEMBANGAN SISTEM INFORMASI AKUNTANSI UNTUK PROSES PRODUKSI PADA PT XYZ
}

\author{
Yohannes Kurniawan; Devyano Luhukay; Titan Halim \\ Information Systems Department, School of Information Systems, Binus University \\ Jln. K.H. Syahdan No. 9, Palmerah, Jakarta Barat 11480 \\ ykurniawan@binus.edu; devyano@binus.edu; titan@binus.edu
}

\begin{abstract}
The purpose of the research is to identify and analyze the need of accounting information system for processes, procedures, and documents related to the production process at PT XYZ, which design the useful of accounting information systems to support business processes that occur. The design method used in this research is a method of Object Oriented Analysis and Design (OOAD) with the UML notation, including: use case diagram, class diagram, and component architecture. Analyzes performed related to the organizational structure and business processes based on the theory of accounting information systems production processes and internal control theory. The result achieved by analysis and design of accounting information systems production process is a desktop based application that can assist in the activities of the production process, especially in the documentation and storage of transaction data, and produce reports in accordance with company requirements. Conclusions derived from the analysis and design is the implementation of a desktop based application that can help PT XYZ to improve systems and procedures, so it can obtain the required information on time and accurately.
\end{abstract}

Keywords: system, Information, accounting, production process, OOAD

\begin{abstract}
ABSTRAK
Penelitian dilakukan dengan mengidentifikasi dan menganalisis kebutuhan sistem informasi akuntasi baik itu proses, prosedur, maupun dokumen yang berkaitan dengan proses produksi pada PT XYZ. Kemudian penelitian melakukan perancangan sistem informasi akuntansi yang berguna untuk mendukung proses bisnis yang terjadi dalam pada proses produksi. Metode perancangan yang digunakan dalam penulisan ini adalah metode OOAD (Object Oriented Analysis and Design) dengan notasi UML yang meliputi: use case diagram, class diagram, dan component architecture, serta perancangan user interface. Analisis yang dilakukan berkaitan dengan struktur organisasi dan proses bisnis yang sedang berjalan berdasarkan teori sistem informasi akuntansi proses produksi dan teori pengendalian internal. Hasil yang dicapai dengan melakukan analisis dan perancangan sistem informasi akuntansi proses produksi adalah adanya aplikasi berbasis desktop yang dapat membantu dalam aktivitas proses produksi, khususnya dalam pendokumentasian dan penyimpanan data-data transaksi, serta menghasilkan laporan sesuai dengan kebutuhan perusahaan. Simpulan yang didapat dari hasil analisis dan perancangan yang dilakukan adalah adanya penerapan aplikasi yang berbasis desktop yang dapat membantu PT XYZ untuk memperbaiki sistem dan prosedur yang sedang berjalan sehingga dapat memperoleh informasi yang dibutuhkan dengan tepat waktu dan akurat.
\end{abstract}

Kata kunci: sistem, informasi, akuntansi, proses produksi, OOAD 


\section{PENDAHULUAN}

Perkembangan teknologi informasi saat ini mendorong perusahaan-perusahaan untuk mengikutsertakan dan menerapkan pemakaian teknologi informasi dalam menjalankan proses bisnis. Komputer telah menjadi salah satu alat penunjang bagi perusahaan untuk menjalankan proses bisnis untuk meningkatkan efektivitas dan efisiensi dalam proses bisnis. Hal serupa juga diungkapkan Ho (1996): "IT is most likely to be used in enhancing manufacturing processes and controlling manufacturing operations. The application of IT in manufacturing organizations either adds to efficiency and precision of manufacturing equipment or facilitates in collecting manufacturing environment information."

Perkembangan bisnis yang makin hari makin cepat menuntut perusahaan untuk dapat bersaing dengan perusahaan lain, baik itu perusahaan dari dalam maupun dari luar negeri. Ditambah lagi dengan adanya era globalisasi, banyak perusahaan asing yang akan menanamkan modal dan berbisnis di Indonesia. Oleh karena itu perusahaan perlu melakukan perbaikan, perubahan, dan inovasi secara terus menerus. Perusahaan harus dapat melihat peluang-peluang yang dapat dimanfaatkan secara maksimal untuk menciptakan suatu nilai tambah (added value) bagi perusahaan tersebut, sehingga perusahaan memiliki keunggulan kompetitif yang memampukannya untuk tetap dapat bertahan dan bersaing bahkan unggul daripada perusahaan-perusahaan lainnya. Hal ini juga diungkapkan oleh Perez-Arostegui, María N, Benitez-Amado, Jose \& Tamayo-Torres, Javier (2012) yang menyatakan bahwa "The existence of a flexible IT infrastructure, IT managerial knowledge and the integration of IT strategy with firm strategy will have a positive impact on firm's competitive position, which is evaluated through quality performance."

Proses produksi harus memiliki perencanaan dan pengendalian yang tepat agar menghasilkan suatu produk sepeda motor yang berdaya nilai jual. Adapun proses pengambilan keputusan harus mengandung informasi yang berkualitas, yaitu relevan, akurat, dan tepat waktu. Keputusan untuk membuat perencanaan produksi sebagai dasar dalam memulai produksi seperti banyak jumlah bahan baku yang akan dibutuhkan, komponen biaya yang akan timbul, perkiraan waktu pelaksanaan kegiatan produksi. Pengendalian biaya produksi seperti biaya tenaga kerja, biaya bahan baku dan biaya overhead, serta perhitungan harga pokok produksi yang tepat sangat dibutuhkan karena akan mempengaruhi harga jual produk. Perusahaan perlu menyusun suatu sistem dan prosedur yang dapat menciptakan pengendalian internal secara memadai dalam mengatur pelaksanaan proses produksi.

Kebutuhan serupa juga diakui oleh pihak manajemen PT XYZ sebagai perusahaan manufaktur yang bergerak dalam bidang perakitan kendaraan bermotor, khususnya kendaraan roda dua. Perusahaan pada saat ini belum memiliki infrastruktur sistem yang terstruktur dan terintegrasi satu dengan yang lainnya. Perusahaan masih menggunakan aplikasi sederhana dalam pencatatan dan pelaporan yaitu menggunakan Microsoft Office Excel. Pada proses produksi, adanya pendokumentasian yang belum cukup untuk mendukung kegiatan produksi, dimana belum terdapat dokumentasi untuk penukaran part yang rusak selama proses perakitan yang berpotensi menimbulkan kecurangan dalam pengelolaan persediaan part. Selain itu, belum adanya surat perintah kerja untuk proses produksi, sehingga berpotensi menimbulkan pelaksanaan perencanaan produksi yang tidak teratur dan terjadinya penumpukan Finished Good dan Semi Finished Good di gudang penyimpanan barang. Pada sistem perhitungan harga pokok produksi, perusahaan membebankan biaya overhead secara rata selama satu bulan dibagi dengan jumlah unit motor yang diproduksi meskipun produk yang diproduksi berbeda-beda. Hal ini berpotensi menimbulkan pembebanan biaya overhead yang tidak proporsional berdasarkan konsumsi pemakaian biaya overhead setiap produk secara aktual, sehingga produk yang memakai biaya overhead yang lebih sedikit ikut terbebani oleh produk yang pemakaian biaya overhead-nya lebih banyak. Perusahaan juga belum dapat menghitung hasil produksi motor setiap harinya dan pembuatan laporan biaya produksi yang dibuat secara otomatis. 
Berdasarkan masalah-masalah tersebut, maka perusahaan membutuhkan penerapan suatu sistem informasi akuntansi proses produksi yang yang dapat menghitung biaya produksi berdasarkan Job Order Costing, dengan pemakaian biaya overhead dibebankan secara aktual. Selain itu penerapan sistem informasi akuntansi proses produksi dengan database yang terintegrasi akan membantu perusahaan dalam menjalankan kegiatan operasional dan memudahkan manajemen dalam melakukan pengolahan data menjadi informasi ke dalam bentuk laporan secara cepat dan akurat sesuai dengan informasi yang dibutuhkan oleh pihak manajerial untuk mendukung pengambilan keputusan.

Sistem informasi sebagai solusi untuk masalah ini, karena menurut Hall (2013) sistem informasi sebagai "the set of formal procedures by which data are collected, processed into information, and distributed to users." Maksud dari sistem informasi adalah membuat serangkaian prosedur formal dengan mengumpulkan data, memproses menjadi informasi, dan mendistribusikan kepada pengguna. Sedangkan Sistem informasi akuntansi menurut Gelinas dan Dull (2008) adalah "Accounting information system (AIS) is a specialized subsystem of the IS. The purpose of this separate AIS was to collect, process, and report information related to the financial aspects of business events.” Artinya, sistem informasi akuntansi merupakan subsistem yang terspesialisasi dari sistem informasi yang bertujuan untuk mengumpulkan, memproses, dan melaporkan informasi yang berhubungan dengan aspek-aspek keuangan dari kegiatan-kegiatan bisnis.

Hall (2013) menjelaskan bahwa aktivitas produksi terjadi di dalam siklus pengonversian bahan baku, tenaga kerja, dan aktiva tetap yang digunakan untuk membuat suatu barang jadi. Terdapat dua kelompok aktivitas produksi, yaitu: (1) aktivitas utama manufaktur yang terdiri dari aktivitas membentuk dan merakit bahan baku menjadi barang jadi dan (2) aktivitas pendukung produksi. Aktivitas ini untuk memastikan bahwa aktivitas utama manufaktur berjalan secara efektif dan efisien.

Jadi dapat disimpulkan bahwa produksi merupakan proses mengubah bahan baku, tenaga kerja dengan menggunakan peralatan, aturan-aturan dalam rangka untuk menghasilkan barang jadi. Menurut Nasution (2003), "sistem produksi merupakan kumpulan dari subsistem-subsistem yang saling berinteraksi dengan tujuan mentransformasi input produksi menjadi output produksi.” Gambar sistem produksi dapat dilihat pada Gambar 1.

\section{SISTEM PRODUKSI}

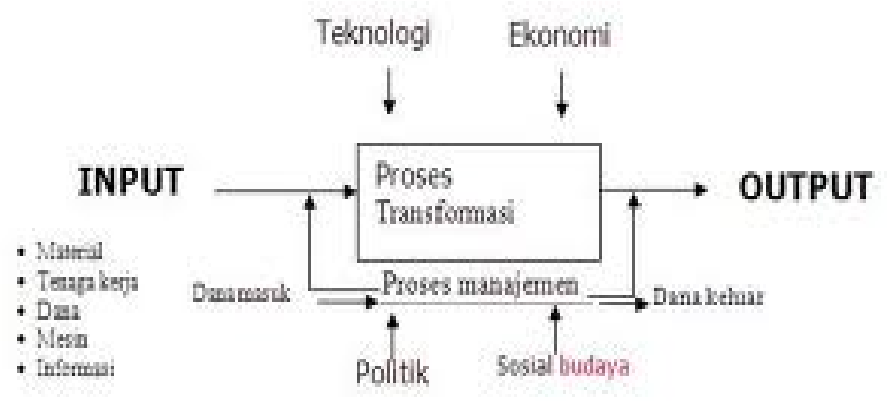

Gambar 1 Input-Output Sistem Produksi

(Sumber: Nasution, 2003) 


\section{METODE}

Perancangan sistem informasi akuntansi proses produksi pada PT XYZ dilakukan dengan melakukan beberapa langkah dan metode penelitian. Perancangan sistem informasi akuntansi diawali dengan penelitian kepustakaan yang dilakukan dengan mengumpulkan referensi dan teori dari buku, artikel dari Internet, jurnal, majalah atau media cetak lain yang berkaitan dengan topik sistem informasi akuntansi proses produksi. Setelah itu penelitian lapangan dilakukan dengan melakukan pengamatan langsung ke lapangan, wawancara dengan para pihak yang terakit dalam proses produksi, dokumentasi dengan menelusuri bukti-bukti beserta dokumen-dokumen yang terkait dengan proses produksi, serta prosedur analisis dengan melakukan penelitian mengenai prosedur yang dijalankan perusahaan. Dokumentasi dari hasil analisis menggunakan unified modeling language yang didasarkan pada unified process disciplines (Satzinger, Jackson, \& Burd, 2005). Hasil analisis kemudian digunakan untuk perancangan sistem yang diusulkan berupa user interface.

\section{HASIL DAN PEMBAHASAN}

\section{Analisis Sistem Berjalan}

Perancangan sistem informasi akuntansi untuk PT XYZ diawali dengan melakukan analisis terhadap sistem yang sedang berjalan. Analisis sistem yang berjalan berguna untuk memahami proses bisnis dan mengetahui kelemahan-kelemahan yang menjadi kendala bagi perusahaan. Adapun perusahaan sampai saat ini masih memiliki kekurangan dalam kegiatan operasionalnya seperti berikut. Pertama, adanya pelaksanaan kegiatan produksi yang hanya berdasarkan Surat Order Produksi. Selama ini, kegiatan produksi dilakukan oleh bagian produksi hanya berdasarkan Surat Order Produksi yang diverifikasi oleh Plant Manager. Namun kenyataannya, banyak produk sepeda motor yang ada pada Surat Order Produksi, setiap kali produksi sepeda motor hanya dapat dilakukan untuk satu jenis produk sepeda motor dengan mempertimbangkan ketersediaan part, kesiapan bagian gudang untuk mengeluarkan part, serta prioritas kebutuhan sepeda motor yang lebih mendesak dari PT XYZ.

Kedua, adanya dokumentasi yang belum memadai dalam pengelolaan persediaan Part pada bagian Production. Komponen Part sepeda motor terdiri dari ratusan komponen mulai dari Part yang kecil hingga besar. Setiap Order produksi dapat memproduksi puluhan hingga ratusan motor. Karenakan komponen tersebut beragam dan banyak, hal tersebut memungkinkan terjadi adanya jumlah Part yang dikirim dari bagian Warehouse tidak sesuai antara Bukti Part Keluar (BPK) dengan jumlah Part yang diterima. Selain itu, perakitan masih dilakukan dengan tenaga manusia yang memungkinkan terjadinya human error pada proses perakitan dan mengakibatkan Part menjadi rusak dan tidak layak untuk dirakit kembali. Oleh karena itu, perusahaan masih belum mempunyai dokumentasi terkait dengan adanya selisih Part yang diterima atau Part yang kurang kirim, dan Part yang diganti serta dikembalikan karena rusak selama proses perakitan.

Ketiga, adanya ketidakseimbangan pembebanan biaya overhead dalam menghitung harga pokok produksi setiap produk. Perhitungan harga pokok produksi selalu ditinjau dari berbagai elemen biaya tertentu. Perusahaan membebankan biaya overhead secara merata selama satu bulan dibagi dengan jumlah unit motor yang diproduksi meskipun produk yang diproduksi berbeda-beda. Hal ini berpotensi menimbulkan pembebanan biaya overhead yang tidak proporsional berdasarkan konsumsi pemakaian biaya overhead setiap produk secara aktual, sehingga produk yang memakai biaya overhead yang lebih sedikit ikut terbebani oleh produk dengan pemakaian biaya overhead lebih banyak. Sebagai contoh, misalnya untuk biaya overhead pada bulan Juli 2013, terlihat berikut ini bahwa total biaya overhead Juli 2013 adalah Rp216,000,000 dan total produksi motor pada Juli 2013 adalah 270 unit yang terdiri dari berbagai jenis dan jumlah produksi motor. Sehingga biaya overhead 
tiap unit motor yang didapat adalah Rp800,000 per unit. Saat ini perusahaan membagi rata biaya overhead satu bulan dengan jumlah produksi motor pada bulan tersebut, yang mengakibatkan produk dengan pemakaian biaya overhead lebih sedikit ikut terbebani oleh produk yang pemakaian biaya overhead lebih banyak, sehingga perhitungan biaya produksi menjadi tidak aktual.

Keempat, adanya mekanisme penyediaan laporan kepada pihak Managerial yang belum memadai. Pihak manajemen mengalami kesulitan untuk memperoleh laporan terkait dengan produksi, persediaan, dan pembelian sewaktu-waktu karena tidak ada sistem pengolahan data yang terkomputerisasi yang dapat menghasilkan laporan dan memberikan informasi secara cepat. Pihak manajemen membutuhkan data yang cepat dan akurat untuk menghasilkan suatu laporan yang berguna bagi pengambilan keputusan Managerial. Kelima, adanya penyimpanan data antarbagian yang belum saling terintegrasi. Selama ini, perusahaan masih menggunakan aplikasi sederhana untuk penyimpanan data, yaitu dengan menggunakan Microsoft Office Excel untuk mendukung berjalannya proses bisnis perusahaan. Adapun penggunaan Microsoft Office Excel tersebut membuat hasil pengolahan data baik berupa dokumen maupun laporan yang belum dapat terhubung, baik pihak pabrik yang membutuhkan data dari kantor pusat maupun pihak kantor pusat yang membutuhkan data dari pabrik, sehingga informasi yang ingin disampaikan dapat menunjang kegiatan proses produksi belum dapat terdistribusi dengan baik

\section{Usulan Penyelesaian Masalah}

Usulan untuk menyelesaikan masalah yang dihadapi perusahaan dalam rangka mendukung sistem informasi yang dirancang adalah sebagai berikut. Pertama, bagian Production seharusnya membuat Surat Perintah Kerja sebagai urutan perintah kepada bagian Assembly atas pelaksanaan perakitan berdasarkan Surat Order Produksi, yang Surat Perintah Kerja berisi satu produk motor yang merupakan penjabaran dari Surat Order Produksi tergantung kepada ketersediaan jumlah Part dalam memenuhi Order produksi dan untuk memudahkan perhitungan harga pokok produksi setiap produk. Kedua, jika ada kondisi jumlah Part yang dikirim dari bagian Warehouse tidak sesuai antara Bukti Part Keluar (BPK) dengan jumlah Part yang diterima, perlu dibuat dokumen Surat Part Kurang Kirim (SPKK) sebagai pengingat dan bukti dokumentasi sehingga Bagian Warehouse dapat dengan segera mengirimkan Part yang kurang tersebut agar proses perakitan dapat berjalan lancar. Serta perlu dibuat Surat Pengganti Part (SPP) untuk Part yang rusak selama proses perakitan agar proses perakitan dapat kembali dilakukan.

Ketiga, merancang suatu sistem produksi yang dapat menghitung biaya produksi berdasarkan Job Order Costing, dengan pemakaian biaya overhead dibebankan secara aktual untuk setiap produk berdasarkan Surat Perintah Kerja. Lalu keempat, merancang suatu sistem informasi akuntansi proses produksi yang dapat melakukan pengolahan data menjadi informasi ke dalam bentuk laporan secara cepat dan akurat sesuai dengan informasi yang dibutuhkan oleh pihak Managerial. Kemudian kelima, diperlukan adanya suatu sistem informasi akuntansi proses produksi dengan database yang terintegrasi dan dapat mendistribusikan dan mengoneksikan data antara kantor pusat dan pabrik.

\section{Perancangan Sistem Informasi Akuntansi}

Setelah melakukan analisis dan merancang sistem yang baru, maka dapat diterapkan suatu sistem informasi akuntansi yang akan menyelesaikan masalah yang dihadapi perusahaan. Penyelesaian masalah yang dihadapi perusahaan dapat terselesaikan melalui prosedur kerja yang baru dirancang dan fitur-fitur pada aplikasi yang akan membantu kegiatan operasional perusahaan serta membantu manajemen memperoleh laporan terkait dengan proses produksi. Secara keseluruhan (overview), gambaran sistem informasi akuntansi produksi yang diusulkan dapat digambarkan melalui use case diagram sebagai berikut (Gambar 2). 


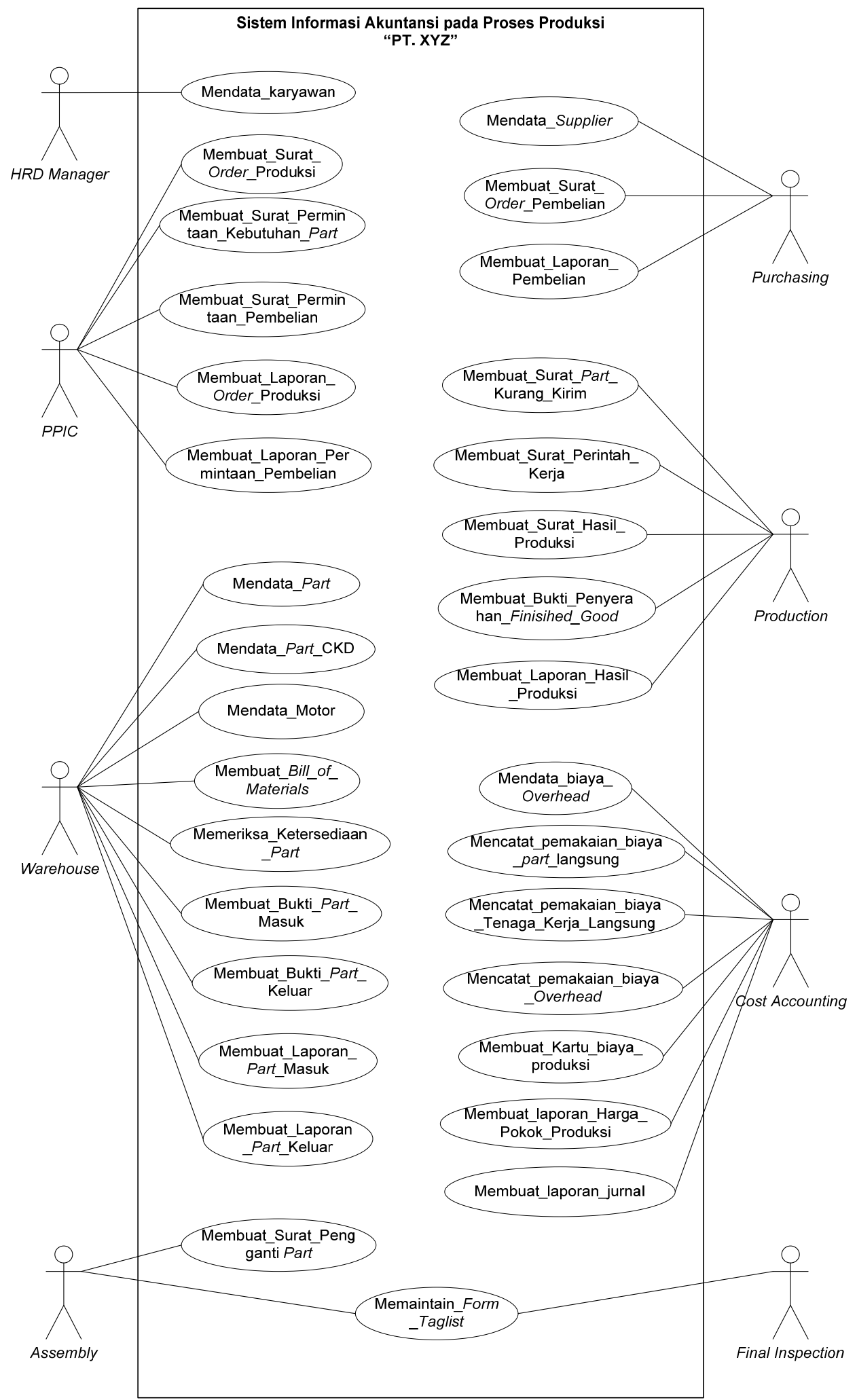

Gambar 2 Use Case Diagram Sistem Informasi Akuntansi Proses Produksi PT XYZ 


\section{Kebutuhan Data terhadap Sistem Informasi yang Diusulkan}

Kebutuhan data sistem informasi akuntansi produksi ini digambarkan melalui class diagram berikut (Gambar 3).

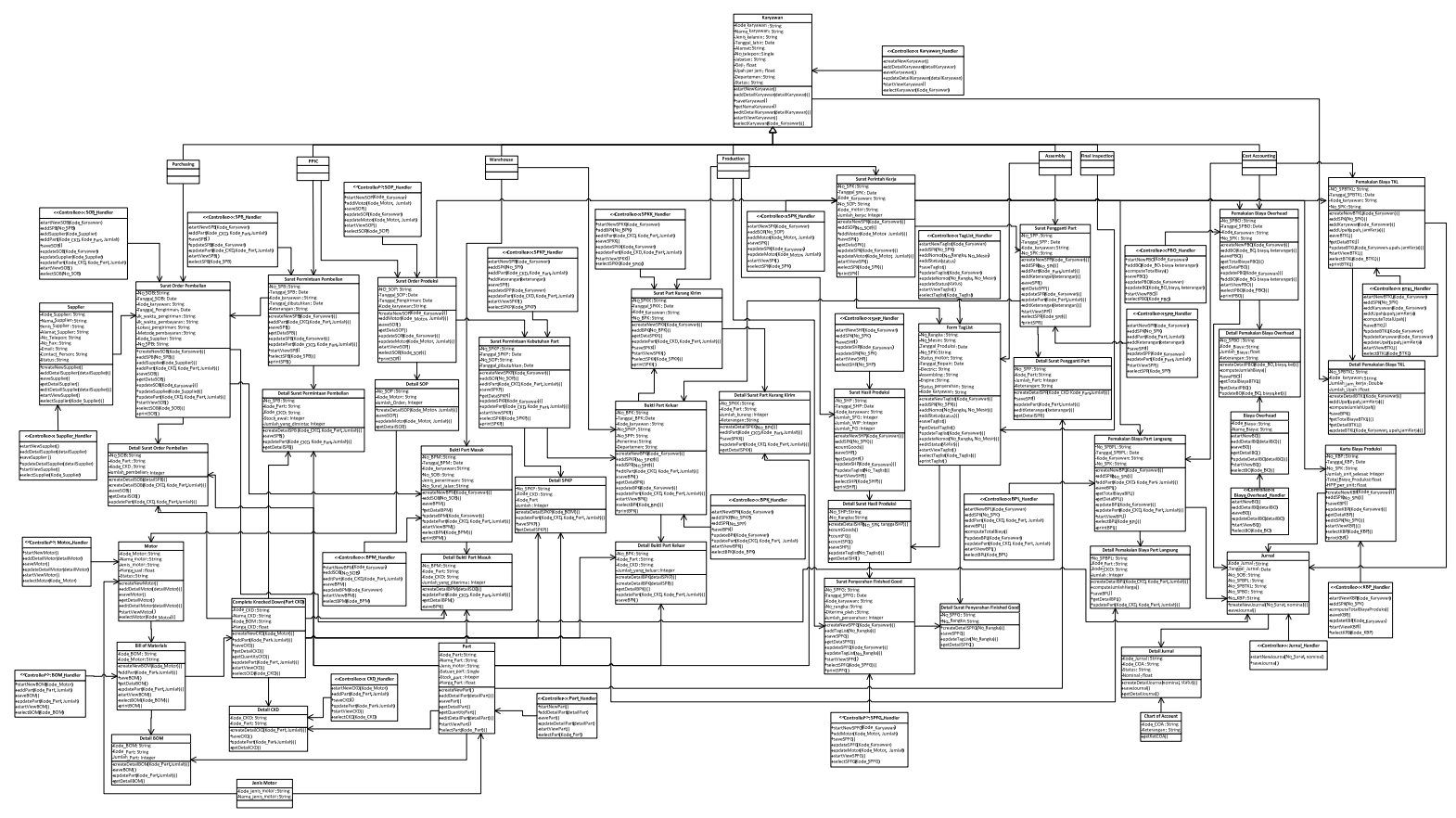

Gambar 3 Class Diagram Sistem Informasi Akuntansi Proses Produksi PT XYZ

\section{Rancangan User Interface}

User Interface yang dirancang dalam pembangunan sistem informasi akuntansi proses produksi PT XYZ adalah sebagai berikut (Gambar 4 sampai Gambar 7).

\section{User Interface Form Master Bill of Materials (BOM)}

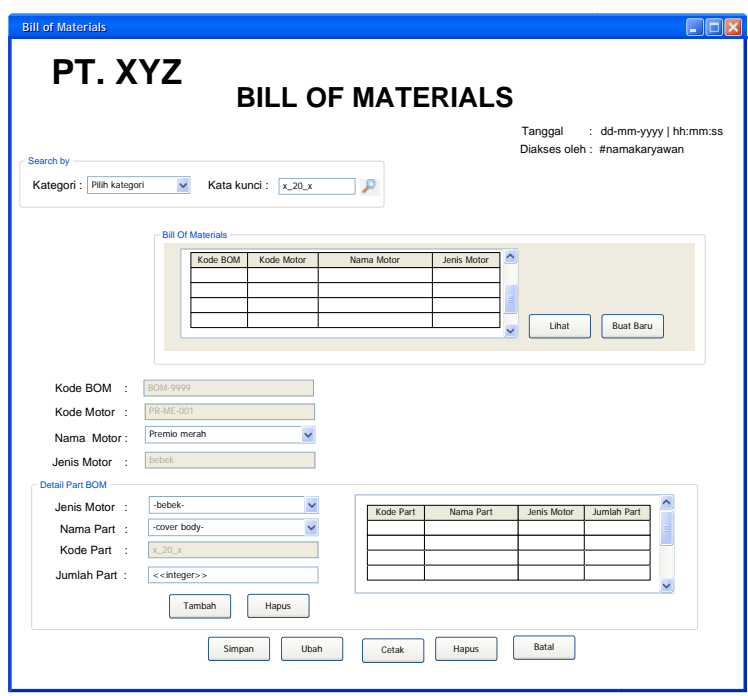

Gambar 4 User Interface Form Master Bill of Materials (BOM) 
Keterangan:

Form Master BOM dibuat oleh Production dan digunakan untuk mengetahui BOM yang dimiliki perusahaan. Ketika form dibuka, sistem akan meng-generate kode BOM terakhir yang ada di dalam database dan Production dapat menekan tombol "Lihat" untuk menampilkan data BOM yang ada di dalam database.

Production dapat mencari data di dalam database Master BOM dengan meng-input kategori atribut yang ingin dicari serta memilih icon kaca pembesar. Production dapat langsung memasukkan data BOM dengan menekan tombol "Buat Baru" dan memasukkan nama motor, serta meng-input nama Part, jenis motor, dan jumlah Part ke dalam field yang disediakan. Setelah menginput data tersebut, Production dapat menekan tombol "Tambah" untuk dimasukkan ke dalam Detail Part BOM atau "Hapus" untuk menghapus data dari Detail Part BOM. Jika ingin meng-update data BOM, Production dapat memilih daftar list table terlebih dahulu, data tersebut akan tersaji dalam field-field yang dapat langsung diubah, setelah selesai Production menekan Tombol "Ubah" yang sistem akan mengubah data yang diubah tersebut ke dalam list table.

Jika telah selesai menambahkan atau mengubah data di dalam list table, Production dapat menekan tombol "Simpan" untuk mengakhirinya; atau tombol "Hapus" untuk menghapus data BOM; atau menekan tombol "Cetak" untuk mencetak dokumen; atau tombol "Batal” jika Production ingin membatalkan penggunaan form dan kembali ke menu utama.

\section{User Interface Form Surat Order Produksi}

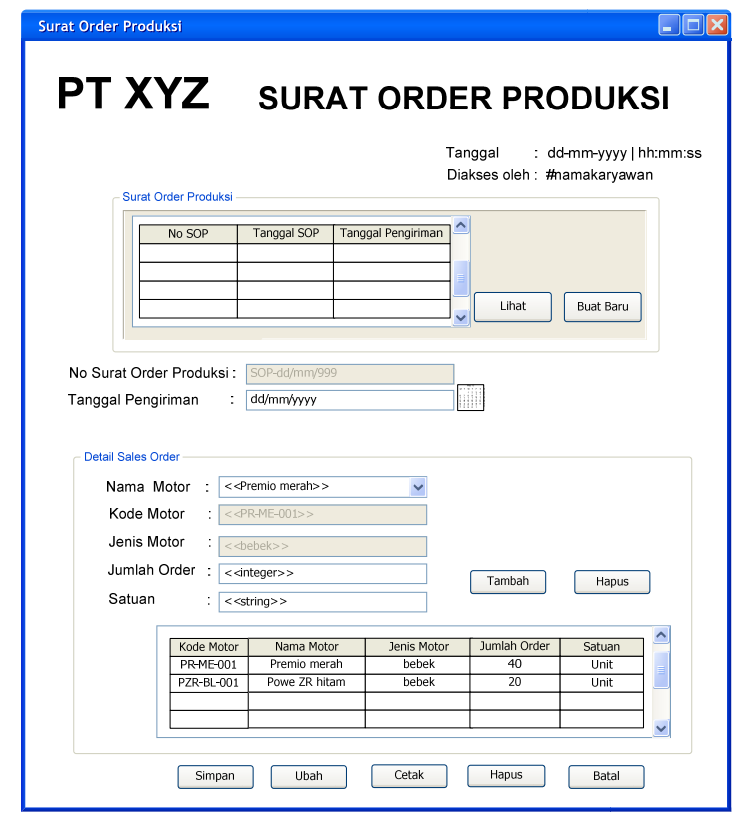

Gambar 5 User Interface Form Surat Order Produksi

Keterangan:

Form Surat Order Produksi dibuat oleh PPIC dan digunakan untuk mengetahui permintaan Order Produksi untuk diserahkan kepada bagian Assembly untuk dilakukan perakitan. Ketika form dibuka, sistem akan meng-generate kode Surat Order Produksi terakhir yang ada di dalam database dan Production dapat menekan tombol "Lihat" untuk menampilkan data Order Produksi yang ada di dalam database. 
PPIC dapat langsung memasukkan data Order Produksi dengan menekan tombol "Buat Baru”, dan memasukkan tanggal pengiriman, serta meng-input nama motor, jumlah motor, dan satuan ke dalam field yang disediakan. Setelah meng-input data tersebut, PPIC dapat menekan tombol “Tambah” untuk dimasukkan ke Detail Sales Order atau "Hapus” untuk menghapus data dari Detail Sales Order. Jika ingin meng-update data Order Produksi, PPIC dapat memilih daftar list table terlebih dahulu, data tersebut akan tersaji ke dalam field-field yang dapat langsung diubah. Setelah selesai PPIC menekan Tombol "Ubah”, sistem akan mengubah data yang diubah tersebut ke dalam list table.

Jika telah selesai menambahkan atau mengubah data di dalam list table, PPIC dapat menekan tombol "Simpan" untuk mengakhirinya; atau tombol "Hapus" untuk menghapus data Order Produksi; atau menekan tombol "Cetak" untuk mencetak dokumen; atau tombol "Batal" jika PPIC ingin membatalkan penggunaan form dan kembali ke menu utama.

\section{User Interface Form Surat Hasil Produksi}

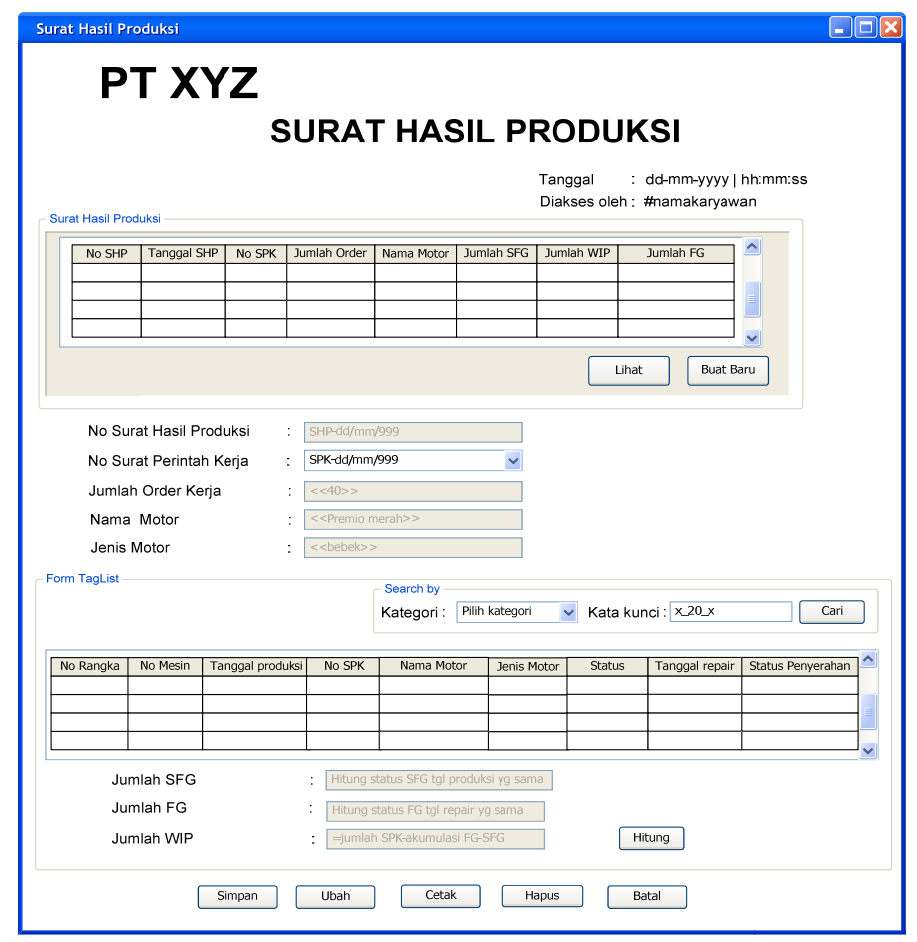

Gambar 6 User Interface Form Surat Hasil Produksi

Keterangan:

Form Surat Hasil Produksi dikelola oleh Production yangdigunakan untuk mencatat jumlah unit yang diproduksi setiap hari berdasarkan Surat Perintah Kerja. Ketika form dibuka, Production dapat menekan tombol "Lihat" untuk menampilkan data Hasil Produksi yang ada di dalam database.

Production dapat langsung memasukkan data Hasil Produksi dengan menekan tombol "Buat Baru”, dan memilih nomor Surat Perintah Kerja. Production kemudian dapat menghitung jumlah Semi Finished Good, Finished Good, dan Work In Process dengan menekan tombol "Hitung". Sistem akan menampilkan hasil perhitungan jumlah tersebut. Jika ingin meng-update data Hasil Produksi, Production dapat memilih daftar list table terlebih dahulu, data tersebut akan tersaji ke dalam fieldfield yang dapat langsung diubah. Setelah selesai Production menekan Tombol "Ubah", sistem akan mengubah data yang diubah tersebut ke dalam list table. 
Jika telah selesai menambahkan atau mengubah data di dalam list table, Production dapat menekan tombol "Simpan" untuk mengakhirinya; atau tombol "Hapus" untuk menghapus data Hasil Produksi; atau menekan tombol "Cetak" untuk mencetak dokumen atau tombol "Batal" jika Production ingin membatalkan penggunaan form dan kembali ke menu utama.

\section{User Interface Form Kartu Biaya Produksi}

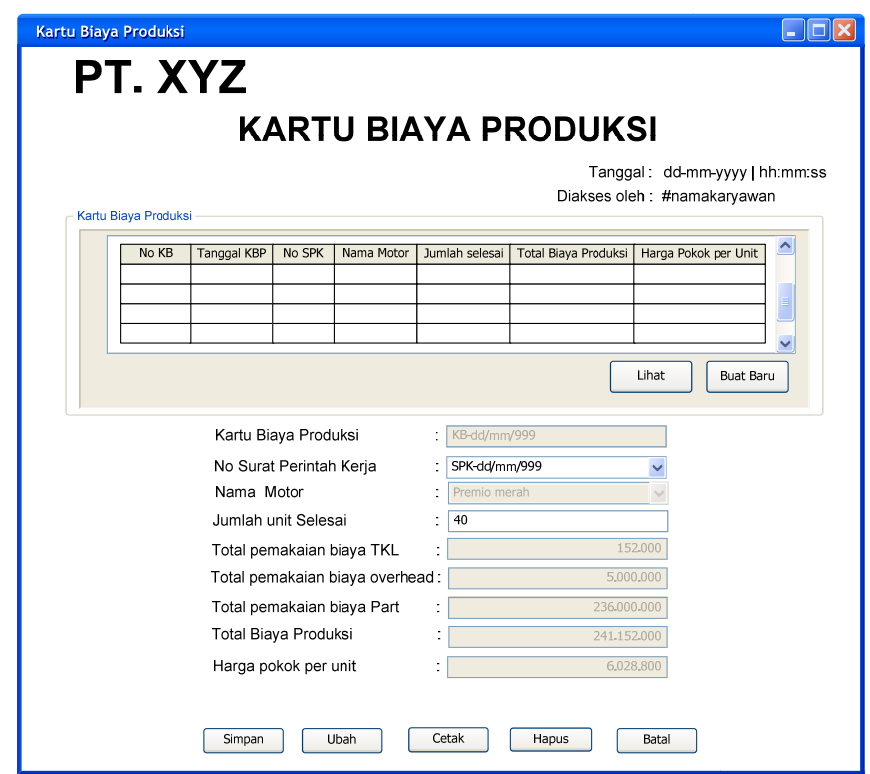

Gambar 7 User Interface Form Kartu Biaya Produksi

Keterangan:

Form Kartu Biaya Produksi dibuat oleh Cost Accounting dan digunakan untuk menghitung total biaya produksi setelah kegiatan produksi berlangsung berdasarkan Surat Perintah Kerja. Ketika form dibuka, sistem akan meng-generate kode Kartu Biaya Produksi terakhir yang ada di dalam database dan Cost Accounting dapat menekan tombol "Lihat" untuk menampilkan dataKartu Biaya Produksi yang ada di dalam database.

Cost Accounting dapat langsung memasukkan data Kartu Biaya Produksi dengan menekan tombol "Buat Baru", dan memilih nomor Surat Perintah Kerja, serta meng-input jumlah unit selesai ke dalam field yang disediakan. Berdasarkan Surat Perintah Kerja yang dipilih, sistem akan menampilkan total pemakaian biaya Part, total pemakaian biaya Overhead, dan total pemakaian biaya tenaga kerja langsung. Kemudian sistem akan menghitung total biaya produksi dan harga pokok per unit. Jika ingin meng-update data Kartu Biaya Produksi, Cost Accounting dapat memilih daftar list table terlebih dahulu, data tersebut akan tersaji ke dalam field-field yang dapat langsung diubah. Setelah selesai Cost Accounting menekan Tombol "Ubah", sistem akan mengubah data yang diubah tersebut ke dalam list table.

Jika telah selesai menambahkan atau mengubah data di dalam list table, Cost Accounting dapat menekan tombol "Simpan" untuk mengakhirinya atau tombol "Hapus" untuk menghapus data Kartu Biaya Produksi atau menekan tombol "Cetak" untuk mencetak dokumen atau tombol "Batal" jika Cost Accounting ingin membatalkan penggunaan form dan kembali ke menu utama. 
Pada saat bagian Cost Accounting menekan tombol "Simpan", maka sistem secara otomatis akan mencatat jurnal pengakuan finished good atas produksi yang telah selesai yaitu:

$$
\begin{aligned}
& \text { Finished Good (D) } \\
& \text { Work In Process(K) }
\end{aligned}
$$

$x \times x \times x x \times x \times x x$

$x x x x x x x x x x$

\section{Component Architecture}

Struktur arsitektur komponen yang dipilih adalah client-server dengan pola Disttributed Functionality. Di client (user) terdapat User Interface dan Function yang akan melakukan request dan System Interface yang akan menyediakan akses terhadap function di server yang akan memproses dan memberikan respons yang diminta. Hal ini bertujuan untuk menjaga konsistensi data transaksi karena sistem dapat diakses melalui aplikasi desktop oleh beberapa client yang berada pada lokasi yang berbeda pada PT XYZ. Data hanya terdapat di pusat karena antara tiap bagian perlu adanya integrasi, oleh karena itu model hanya akan terdapat di server untuk menjaga konsistensi data, dapat dilihat pada Gambar 8.

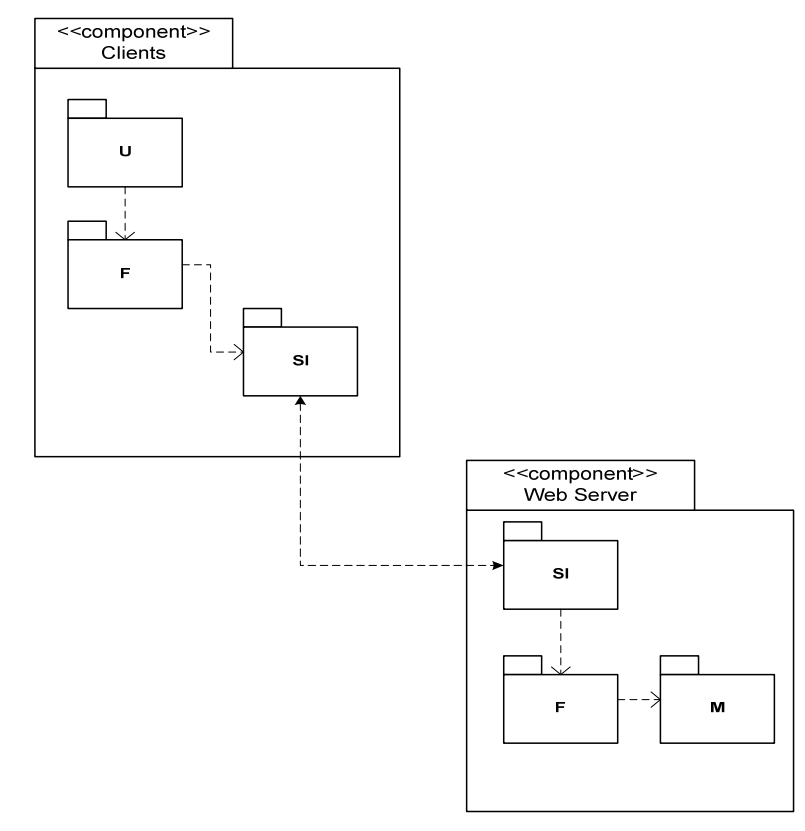

Gambar 8 Component Diagram Sistem Informasi Akuntansi Proses Produksi pada PT XYZ

\section{SIMPULAN}

Berdasarkan hasil analisis dan perancangan sistem informasi akuntansi terhadap proses produksi pada PT XYZ, maka dapat diperoleh simpulan sebagai berikut. Pertama, terkait dengan pelaksanaan kegiatan produksi, yang dari banyak produk kendaraan yang terdapat pada Surat Order Produksi, setiap kali produksi sepeda motor hanya dapat dilakukan untuk satu jenis produk sepeda motor dengan mempertimbangkan ketersediaan part, kesiapan bagian gudang untuk mengeluarkan part, serta prioritas kebutuhan sepeda motor yang lebih mendesak. Hal ini dapat didukung dengan dibuatnya Surat Perintah Kerja pada sistem yang akan dikembangkan sebagai urutan perintah kepada 
bagian Assembly atas pelaksanaan perakitan berdasarkan Surat Order Produksi, sehingga dapat memperjelas produk mana yang harus diproduksi terlebih dahulu. Kedua, selain itu terkait dengan dokumentasi dalam pengelolaan persediaan Part pada bagian Production, perusahaan masih belum mempunyai dokumentasi terkait dengan adanya selisih Part yang diterima atau Part yang kurang kirim dari bagian Warehouse ke bagian Production. Hal tersebut berpotensi menimbulkan kecurangan dalam pengelolaan persediaan part, sehingga sebagai solusi pada sistem yang akan dikembangkan dilengkapi dengan fitur membuat dokumen Surat Part Kurang Kirim (SPKK) sebagai pengingat dan bukti dokumentasi kepada Bagian Warehouse agar dapat dengan segera mengirimkan Part yang kurang kirim tersebut agar proses perakitan dapat berjalan lancar.

Ketiga, dan terkait dengan pembebanan biaya overhead dalam perhitungan harga pokok produksi setiap produk, adanya ketidakseimbangan pembebanan biaya overhead setiap produk secara aktual. Selama ini perusahaan membebankan biaya overhead secara merata selama satu bulan dibagi dengan jumlah unit motor yang diproduksi, meskipun produk yang diproduksi berbeda-beda, sehingga produk yang memakai biaya overhead yang lebih sedikit ikut terbebani oleh produk yang pemakaian biaya overheadnya lebih banyak. Hal ini dapat didukung dengan sistem informasi akuntansi proses produksi yang dapat menghitung biaya produksi berdasarkan Job Order Costing, sehingga bagian Cost Accounting dapat mencatat pemakaian biaya overheadyang dibebankan secara aktual untuk setiap produk berdasarkan setiap Surat Perintah Kerja. Keempat, terkait dengan penyimpanan data antarbagian, yang belum saling terintegrasi yang membuat hasil pengolahan data baik berupa dokumen maupun laporan belum dapat terhubung. Hal ini dapat didukung dengan adanya sistem informasi akuntansi proses produksi dengan database yang terintegrasi dan dapat mendistribusikan dan mengoneksikan data antara kantor pusat dan pabrik, sehingga dapat membantu dalam menyediakan.

\section{DAFTAR PUSTAKA}

Gelinas, U. J., \& Dull, R. B. (2008). Accounting Information System ( $7^{\text {th }}$ Edition). Canada: Thomson South-Western.

Hall, J. A. (2013). Introduction to Accounting Information System (8 ${ }^{\text {th }}$ Edition). Canada: SouthWestern Cengage Learning.

Ho, C. (1996). Information technology implementation strategies for manufacturing organization: a strategic alignment approach. International Journal of Operations \& Production Management, 16(7), 77-100.

Nasution, A. H. (2003). Perencanaan \& Pengendalian Produksi edisi ke 1 jilid 2. Surabaya: Prima Printing.

Perez-Arostegui, María N, Benitez-Amado, Jose \& Tamayo-Torres, Javier. (2012). Information technology-enabled quality performance: an exploratory study. Industrial Management \& Data Systems, 112(3), 502-518.

Satzinger, J. W., Jackson, R. B., \& Burd, S. D. (2005). Object Oriented Analysis and Design with the Unified Process. USA: Course Technology. 